\title{
VARIATION OF SOME MEAT QUALITY INDICES IN ECTOPARASITE POLYPARASITIZED AND ANTIPARASITIC TREATED HENS
}

\section{Maria Zamornea $^{1}$, Dumitru Erhan', ${ }^{1}$ Stefan Rusu ${ }^{1}$, Oleg Chihai ${ }^{1}$, Lidia Bondari²}

\begin{abstract}
${ }^{1}$ Institute of Zoology, Chisinau, Republic of Moldova, e-mail: mariazamornea@gmail.com ${ }^{2}$ College of Ecology, Chisinau, Republic of Moldova
\end{abstract}

\begin{abstract}
As a result of the conducted research it was established, that the meat quality of hens polyparasitized with malophages (Cuclotogaster heterographus, Eomenacanthus stramineus, Goniocotes gallinae, Goniocotes maculatus, Goniodes dissimilis, Lipeurus caponis, Menopon gallinae, Menacanthus cornutus, Menacanthus pallidulus) fleas (Ceratophylus gallinae, C. hirundinis) and mites (Dermanyssus gallinae, D. hirundinis), then treated with Ectostop T5\%, Ectostop P5\%, showed a protein content of $20.5 \pm 0.20 \%$, a pH of $5.3 \pm 0.12$ and a moisture content of $65.4 \pm 0.21 \%$, these indices reaching the level of the non-infested batch (control).

The protein level is low in the meat samples of batch II (untreated infested), constituting $16.22 \pm 0.03 \%$, and in batch VII treated with Ivomec chemical preparation $17.02 \pm 0.87 \%$. The meat moisture index is characterized by a greater difference for batch II and VII constituting $74.52 \pm 0.18 \%$ and $70.1 \pm 0.05 \%$ respectively. The $\mathrm{pH}$ assessed in untreated infested and Ivomec-treated hens is alkaline, which will lead to decreased keeping capacity.
\end{abstract}

\section{Introduction}

One of the main directions of the technical and scientific policy of the state, in the direction of maintaining a decent food supply of the population, is to provide it with quality food products. In the Republic of Moldova, a number of legislative documents have been adopted in recent years to protect the domestic consumer [10]. Moreover, bibliographical data show that the impact of parasitosis and antiparasitic preparations on the bacteriological status, vitamin, micro- and macroelement content of the parasitized organism is considerable $[3,4]$.

Poultry meat has numerous organoleptic and nutritional properties, is low in calories and high in protein (21.0-22.0\%), and occupies a special place in human nutrition because of its quality. The muscle tissue is more compact, the muscle fibres are finer, the sarcolemma is very thin and the meat is thinner, the connective tissue in it is less, blood irrigation is minimal. All these structural properties give it a good digestibility, making it a dietary meat. It contains a higher percentage of vitamins than mammalian meat $[5,7,11]$.

The main physical characteristic of meat is its acidity $(\mathrm{pH})$, which determines and reflects the state of its chemical components. The importance of the $\mathrm{pH}$ of meat is determined by the fact that it is directly or indirectly related to: colour, tenderness, aroma and taste, water holding capacity. It is appreciated that meat $\mathrm{pH}$ is influenced primarily by non-genetic factors (physical activity, diet duration, maintenance status, parasite stress, temperature, etc.), as well as some genetic factors (species), individual specificity of response, etc. [2, 12].

In addition to the aforementioned characteristics, some authors highlight the importance of meat moisture. The greater or lesser moisture content of meat is related to its capacity to retain 
its own water and, in particular, so-called 'free water', which depends on a large number of factors after slaughter [13].

At the same time, according to the World Health Organisation, animal production must be ecologically pure and harmless to the environment. International trade of animals, meat and meat products, the active movement of tourists and globalisation exacerbate and increase the risk of parasitic zoonoses [9]. An effective compliance programme ensures that the requirements of EU legislation and, where applicable, national legislation and other international standards, which are related to the production of food for human consumption, are met [1].

\section{Materials and methods}

The research was carried out during 2015-2020 in the Parasitology and Helminthology laboratory of the Institute of Zoology. Malophagia, fleas and gamasid mites were collected from live birds, according to a new procedure for collecting ectoparasites from live birds [6], and from hen houses, by applying rubber systems placed in cages and nests (mite hiders). The collected material was further examined using the МБС-9 magnifying glass (ob. x 4) and the МБИ -3 microscope (ob. x 10). The population structure of ectoparasites (developmental stages: eggs, larvae, nymphs and imago) was studied, determining the quota, share of eggs, larvae, nymphs and imago. The method applied is effective for collecting various groups of ectoparasites from live birds.

In order to elucidate the indices of meat chemical composition ( $\mathrm{pH}$, protein, lipid and moisture content), 35 6-month-old Adler's Silver breed chickens were trained in the experiment. Initially the chickens were polyparasitized and then treated with plant preparations Ectostop T5\% (extract from dried aerial parts of tobacco (Nicotiana rustica L.), Ectostop P5\% (natural biologically active extract obtained from plant raw material of wormwood (Artemisia absinthium L.). and the chemical preparation Ivomec. The birds were divided into seven equal groups: group I - control (non-infested); groups II-VII - infested with malophagous (Cuclotogaster heterographus, Eomenacanthus stramineus, Goniocotes gallinae, Goniocotes maculatus, Goniodes dissimilis, Lipeurus caponis, Menopon gallinae, Menacanthus cornutus, Menacanthus pallidulus), with fleas (Ceratophylus gallinae, C. hirundinis) and mites (Dermanyssus gallinae, D. hirundinis).

Batch I - control (uninfested chickens); batch II - untreated, batch III - treated with Ectostop T5\% at a dose of $50 \mathrm{ml}$ per bird by spraying, (aqueous solution); batch IV - treated with Ectostop T5\% at a dose of $50 \mathrm{ml}$ per bird by spraying (aqueous solution); lot $\mathrm{V}$ - with Ectostop $\mathrm{P} 5 \% \%$ in a dose of $50 \mathrm{ml}$ per bird by spraying (hydroalcoholic solution); lot VI - with Ectostop P5\% in a dose of $50 \mathrm{ml}$ per bird by spraying (aqueous solution); lot VII - with Ivomec 1\% in a dose of $0.2 \mathrm{ml}$ administered subcutaneously in one dose. At the end of the experiment (after 35 days) the chickens were sacrificed. Meat samples of 100-150 g were collected individually from each bird. Protein, lipid, $\mathrm{pH}$ value and moisture content were determined in the meat samples according to classical methods in the laboratory of I.P. Republican Centre for Veterinary Diagnosis (I.P.C.R.D.V.). 


\section{Results and discussion}

The analysis of the obtained data reveals that the $\mathrm{pH}$ level in the chickens of batch I was $5.3 \pm 0.08$, for batch II this index increased and was $7.2 \pm 0.15$ or $35.8 \%(p>0.9)$ higher than batch I (tab. 1). In batches III, IV and V the $\mathrm{pH}$ values were identical, $5.5 \pm 0.17$, but $30.9 \%$ $(p<0.9)$ lower than batch II and 3.7\% ( $>0.9)$ higher than batch I. The $\mathrm{pH}$ value in batch VI was at the same level as batch I index of $5.3 \pm 0.12$. In batch VII this index reached $6.3 \pm 0.13$, was $18.8 \%(\mathrm{p}>0.9)$ higher than batch I, but $12.5 \%(\mathrm{p}<0.9)$ lower than batch II, and $14.2 \%(\mathrm{p}>0.9)$ higher than batches III, IV and V (fig.1).

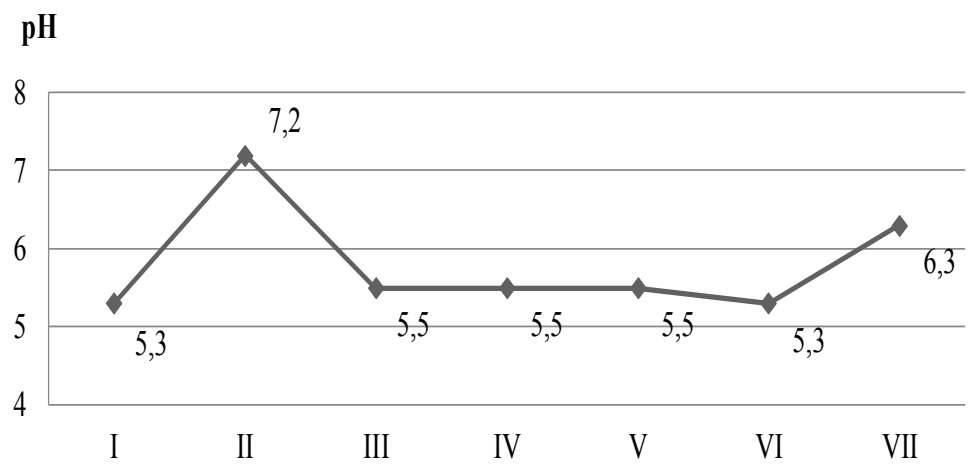

\section{B A T C H}

Figure 1. Chick pH levels in muscle tissue of polyparasitized and treated chickens

Another index characterising meat quality is the moisture content. This index reached a level of $63.78 \pm 1.52 \%$ in batch I or $16.8 \%(\mathrm{p}<0.9)$ lower than batch II. In batch II the meat moisture index has the highest level of $74.52 \pm 0.18 \%, 14.2 \%(\mathrm{p}>0.9)$ higher than in batches III, IV V and VI. In batch VII this index reaches $70.1 \pm 0.05 \%, 7.5 \%(\mathrm{p}>0.9)$ higher than in batches III, IV, V and VI, and 9.9\% ( $p>0.9)$ higher than in batch I, but $6.0 \%(p<0.9)$ lower than in batch II (tab. 1).

Table 1. Chemical composition of muscle tissue in chickenspolyparasitized and after antiparasitic treatment

\begin{tabular}{|c|c|c|c|c|c|}
\hline Batch & Probe numb. & $\mathbf{p H}$ & $\begin{array}{c}\text { Protein, } \\
\mathbf{\%}\end{array}$ & $\begin{array}{c}\text { Lipid, } \\
\mathbf{\%}\end{array}$ & $\begin{array}{c}\text { Moisture, } \\
\mathbf{\%}\end{array}$ \\
\hline I & 5 & $5.3 \pm 0.08$ & $21.0 \pm 0.01$ & $6.22 \pm 0.14$ & $63.78 \pm 0.52$ \\
\hline II & 5 & $7.2 \pm 0.15$ & $16.22 \pm 0.03$ & $2.54 \pm 0.15$ & $74.52 \pm 0.18$ \\
\hline III & 5 & $5.5 \pm 0.17$ & $20.36 \pm 0.27$ & $9.16 \pm 0.06$ & $65.1 \pm 0.05$ \\
\hline IV & 5 & $5.5 \pm 0.16$ & $20.5 \pm 0.20$ & $9.24 \pm 0.11$ & $65.0 \pm 0.05$ \\
\hline V & 5 & $5.5 \pm 0.17$ & $20.3 \pm 0.10$ & $9.20 \pm 0.13$ & $65.0 \pm 0.05$ \\
\hline VI & 5 & $5.3 \pm 0.12$ & $19.0 \pm 0.10$ & $8.50 \pm 0.21$ & $65.40 \pm 0.21$ \\
\hline VII & 5 & $6.3 \pm 0.13$ & $17.02 \pm 0.87$ & $7.22 \pm 0.13$ & $70.10 \pm 0.05$ \\
\hline
\end{tabular}

The result of the analysis shows that the protein level in the meat was $21.0 \pm 0.01 \%$ in batch 
I and $16.22 \pm 0.03 \%$ in batch II, or $22.8 \%(\mathrm{p}<0.9)$ lower than in batch I. In batches III, IV and $\mathrm{V}$ this index was approximately at the same level of $20.36 \pm 0.27 \%, 3.1 \%(\mathrm{p}<0.9)$ lower than in batch I and 25.5\% ( $>0.9)$ higher than in batch II. This index reached $19 \pm 0.01 \%$ in group VI, 9.6\% lower $(\mathrm{p}<0.9)$ than group I but $17.1 \%$ higher $(\mathrm{p}>0.9)$ than group II. In group VII this index reached $17.02 \pm 0.87 \%$ and was $19.1 \%$ lower $(\mathrm{p}<0.9)$ than group I, but $4.9 \%$ higher $(\mathrm{p}>0.9)$ than group II (fig. 2).

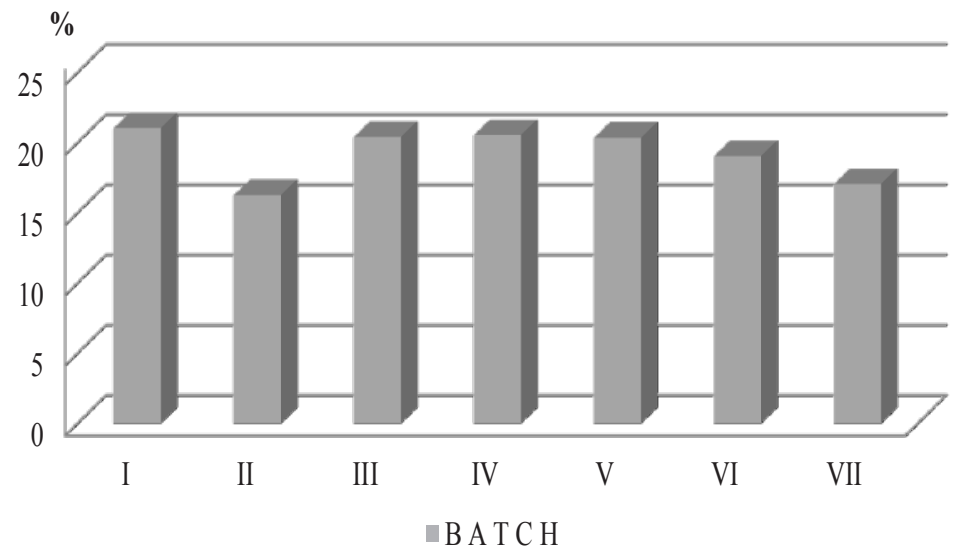

Figure 2. Protein content in muscle tissue of polyparasitized and treated chickens

Analyses carried out to determine the lipid level in chickens after antiparasitic treatment show that in group I - control, this index reached $6.22 \pm 0.14 \%$ or 2.5 times higher than in group II (infested, untreated). An insignificant difference in this index was recorded between batches III, IV and V, with an average of $9.24 \pm 0.11 \%, 48.5 \%(\mathrm{p}>0.9)$ higher than batch I, and a significant increase of $72.6 \%(\mathrm{p}>0.9)$ compared to batch II. In batch VI the lipid content reached $8.5 \pm 0.21 \%, 36.6 \%(\mathrm{p}>0.9)$ higher than batch $\mathrm{I}$ and $70.6 \%(\mathrm{p}>0.9)$ higher than batch II. In group VII the lipid level was $7.22 \pm 0.13 \%, 16.0 \%(\mathrm{p}>0.9)$ higher than group I and $64.9 \%$ ( $>0.9$ ) higher than group II (fig. 3).

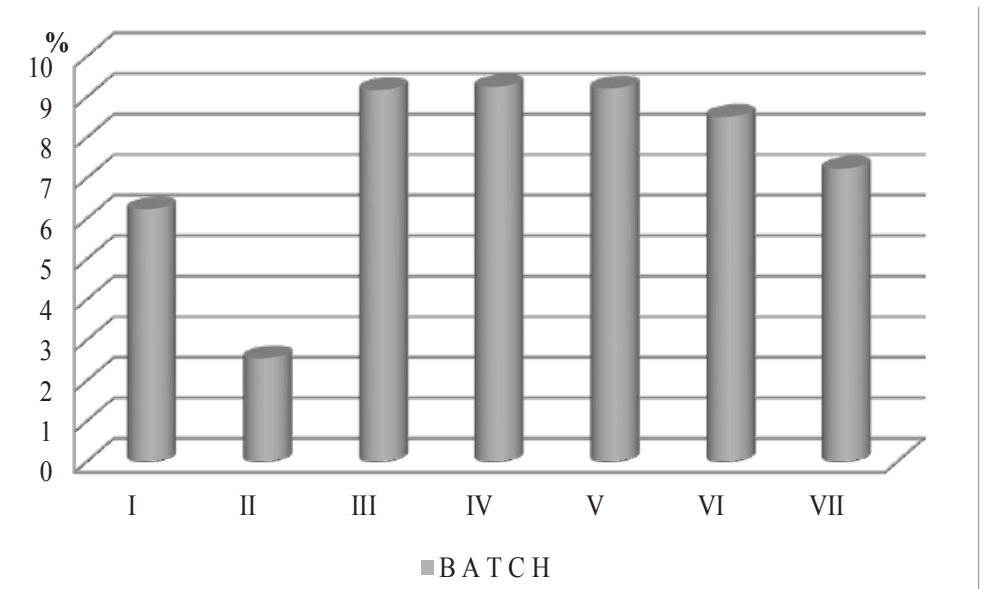

Figure 3. Lipid levels in muscle tissue of polyparasitized and treated chickens 
Therefore, the analyses carried out show that the meat quality of birds polyparasitised with malophages: (Cuclotogaster heterographus, Eomenacanthus stramineus, Goniocotes gallinae, Goniocotes maculatus, Goniodes dissimilis, Lipeurus caponis, Menopon gallinae, Menacanthus cornutus, Menacanthus pallidulus) fleas: (Ceratophylus gallinae, C. hirundinis) and mites (Dermanyssus gallinae, D. hirundinis), then treated with Ectostop T5\%, Ectostop P5\% plant preparations, showed a higher protein content $(20.5 \pm 0.20 \%)$, a lower $\mathrm{pH}$ level $(5.3 \pm 0.12)$ and a lower moisture content $(65.4 \pm 0.21 \%)$, these indices being within the level of the non-infested batch (control). Protein content is low in the meat samples in batch II (untreated infested), constituting $16.22 \pm 0.03 \%$ and in batch VII treated with Ivomec preparation constituting $17.02 \pm 0.87 \%$. The meat moisture index is characterized by a greater difference for batch II and VII constituting $74.52 \pm 0.18 \%$ and $70.1 \pm 0.05 \%$ respectively. The PH level determined in both infested, untreated (batch II) and Ivomec-treated chickens is alkaline and constitutes $7.2 \pm 0.15$ and VII $6.3 \pm 0.13$ respectively, which will lead to a decrease in keeping capacity.Based on the results obtained, the meat of the chickens in batches III-VI has a higher protein content, lower $\mathrm{pH}$ level and lower moisture content, which allows it to be preserved for a longer period of time and is therefore of a much higher quality compared to batch II (untreated) and batch VII (treated with Ivomec). The use of extracts of natural origin with anti-parasitic action ensures that the preparation is not toxic to the animal organism and does not impose restrictions on the use of products and by-products The studies were carried out within the research project no. 20.80009.7007.12.

\section{Bibliography}

1. Autoritatea Europeană pentru Siguranța Alimentelor-http://www.efsa.eu.

2. Barbu L. Contribuții la cunoașterea calității cărnii de pasăre și la valorificarea superioară a acesteia, în conditiiile SC “TABCO-CAMPOFRIO” SA Tulcea. Teză de doctor, Iași, 2010.

3. Dărăbuș G., Oprescu I., Morariu,S., Mederle Narcisa. Parazitologie şi boli parazitare.Ed., Mirton, Timișoara. 2006, 836 p.

4. Erhan D., Rusu, Ș., Tomșa M., etc.Impactul parazitozelor asupra indicilor calitativi ai produselor comestibile de origine animală. The materials of the International Symosium "Actual problems of zoologyandparasitology: achievementsandprospects"dedicatedtothe 100th anniversaryfromthebirth of academician Alexei Spassky, one of thefounders of the Academy of Science of Moldova and of theParasitologicalachool of the Republic of Moldova, 13 October 2017. Chișinău, 2017, p. 138-139.

5. Indicatorii de Calitate ale Cărnii https://ro.scribd.com/document/35956769/.

6. Luncaşu M., ZamorneaM. Procedeu de colectare a ectoparaziţilor de la păsări.Brevet de invenţie 3441 G2, MD, BOPI nr.12, 2007.

7. Şindilar E., Stratan N. Expertiza sanitar-veterinară a alimentelor de origine animală. Chişinău: Tipografia Centrală, 1996, Vol. I, 325 p.

8. Şindilar E., Stratan N. Expertiza sanitar-veterinară a alimentelor de origine animală. Chişinău: Tipografia Centrală, 1996, Vol.II, 340 p.

9. Șuteu I., Cozma V. Parazitologie clinică veterinară. Cluj-Napoca, 2007, Vol.II, 349 p.

10. Tomșa Mihail. Siguranța alimentelor.Chișinău, 2018, 619 p.

11. Колоболотский А. Практикум по ветеринарно-санитарной экспертизе. Москва: Агропромиздат, 1980, 304 с.

12. Макаров В. А. Практикум по ветеринарной-санитарной экспертизе с основами технологии продуктов животноводства. Москва: Агропромиздат, 1987, 271 с.

13. Мысик А., Белова С. Справочник по качеству продуктов животноводства. Москва: Агропромиздат, 1986, 238 с. 